\title{
Response of stevia to foliar application of prilled urea
}

\author{
M. M. Zaman, M. A. H. Chowdhury ${ }^{1^{*}}$ and Tanzin Chowdhury ${ }^{2}$ \\ Soil Resource Development Institute, Farmgate, Dhaka and ${ }^{1}$ Department of Agricultural Chemistry, ${ }^{2}$ Department of \\ Agronomy, Bangladesh Agricultural University, Mymensingh-2202, *E-mail: akhterbau11@gmail.com
}

\begin{abstract}
Urea can be supplied to plants through the foliage, facilitating optimal $\mathrm{N}$ management, which minimizes $\mathrm{N}$ losses to the environment. The efficiency of $\mathrm{N}$ assimilation through foliage depends upon several factors including $\mathrm{N}$ levels and varieties or genotypes. No information is available on the effect of the foliar application of urea on stevia (Stevia rebaudiana, Bertoni). The objective of the study was to evaluate the effect of foliar application of prilled urea applied in different concentrations on the growth, yield components, leaf biomass yield, $\mathrm{N}$ content and its uptake by stevia. Seven levels of urea viz. 0.0, 0.5, 1.0, 1.5, 2.0, 2.5 and $3 \mathrm{~g} \mathrm{2L}^{-1}$ were sprayed 10 days after planting (DAP) in acid and non-calcareous soils at an interval of one week up to 60 DAP. Foliar urea application significantly increased plant height, branch and leaf number, leaf area, fresh and dry leaf weight, leaf $\mathrm{N}$ content and uptake by stevia. Most of the parameters were increased with the advancement of growth period from 30 to $60 \mathrm{DAP}$. The foliar spray of $2.0 \mathrm{~g}$ urea solution was found to be most effective for enhancing the growth, leaf yield and yield attributes of stevia. The yield increase was $478 \%$ in acid soil and $485 \%$ in non-calcareous soil over control. Further increase in the concentrations of urea spray (2.5 and $3.0 \mathrm{~g}$ ) was not found to be useful as it declined the leaf yield by $135 \%$ in acid and $175 \%$ in noncalcareous soil probably due to its toxicity. $\mathrm{N}$ content in stevia leaves was significantly increased with the increased levels of urea up to $3.0 \mathrm{~g}$ in both soils. Conversely, the trend of $\mathrm{N}$ uptake did not follow the trend of $\mathrm{N}$ contents of stevia leaves. $\mathrm{N}$ uptake as expected increased as foliar application of urea increased up to $2.0 \mathrm{~g}$ and then decreased

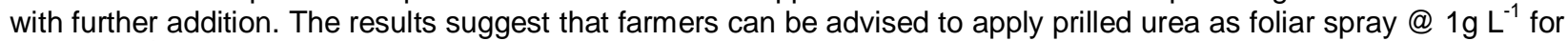
higher leaf biomass yield and $\mathrm{N}$ uptake by stevia either in acid or non-calcareous soils under the agro-climatic conditions of Bangladesh Agricultural University, Mymensingh.
\end{abstract}

Keywords: Stevia, Prilled urea, Foliar application, Leaf yield, N uptake

\section{Introduction}

The role of macro and micro nutrients is crucial in crop nutrition for achieving higher yields (Raun \& Johnson, 1999). The soils of Bangladesh are deficient in nitrogen (N) and are supplemented with chemical fertilizer for enhancing the crop productivity. Nitrogenous fertilizers play a vital role in modern farm technology though only $20-50 \%$ of the soil applied $\mathrm{N}$ is recovered by the annual crops (Bajwa, 1992). Both excess and insufficient $\mathrm{N}$ applications may cause either yield reduction or some physiological disorders. The partial and in-efficient use of $\mathrm{N}$ results in lower crop harvests. The left over $\mathrm{N}$ is lost from the soil system through denitrification, volatilization and leaching.

Foliar fertilization, that is nutrient supplementation through leaves, is an efficient technique of fertilization which enhances the availability of nutrients. It has been observed that utilization of fertilizers especially urea applied through soil is not as effective as when it is supplied to the plant through foliage along with soil application (Mosluh et al., 1978). The interest in foliar fertilizers arose due to the multiple advantages of foliar application methods such as rapid and efficient response to the plant needs, less product needed, and independence of soil conditions. A high penetration rate is one of the pre-requisites for efficient foliar nutrition. Urea, due to its intrinsic characteristics such as small molecular size, non-ionic nature and high solubility, is usually taken up rapidly through the leaf cuticle.

Urea can be supplied to plants through the foliage, facilitating optimal $\mathrm{N}$ management, which minimizes its losses to the environment. Most plants absorb foliar applied urea rapidly and hydrolyze the urea in the cytosol (Witte et al. 2002). The beneficial effects expressed as an increase in yield and an improvement of crop quality were reported in many vegetable species such as cabbage, onion, cucumber, squash (Padem and Yildirim 1996, Kolota and Osinska 2001). The absorption rate of mineral nutrients by aboveground plant parts considerably differs not only among plant species but also among varieties within the same species (Wojcik 2004). The efficiency of $N$ assimilation through foliage, however, depends upon several factors including varieties or genotypes. No information is available on the effect of the foliar application of urea on stevia. Therefore, the study under report was initiated to investigate the effects of foliar application of urea on growth, yield components, leaf biomass yield, $\mathrm{N}$ content and uptake by stevia leaf. 


\section{Materials and Methods}

A pot experiment was conducted at the net house of the Department of Agricultural Chemistry, Bangladesh Agricultural University, Mymensingh during March to May, 2012 to evaluate the effects of different levels of foliar application of urea on yield, yield components, $\mathrm{N}$ content and uptake by stevia. Two soils viz. acid and non-calcareous of contrasting physical and chemical properties were used (Table 1).

Table 1. Physical and chemical properties of acid and non calcareous soil used for the experiment

\begin{tabular}{|c|c|c|}
\hline Soil properties & Acid soil & Non calcareous soil \\
\hline Texture & Clay & Sandy clay loam \\
\hline $\mathrm{pH}$ & 5.10 & 6.70 \\
\hline $\mathrm{EC}\left(\mathrm{dS} \mathrm{m^{-1 } )}\right.$ & 0.25 & 0.67 \\
\hline $\mathrm{OM}(\%)$ & 1.56 & 1.80 \\
\hline Total N (\%) & 0.09 & 0.11 \\
\hline Available $\mathrm{P}$ ( $\mathrm{gg} \mathrm{g}^{-1}$ soil) & 3.00 & 12.00 \\
\hline Exchangeable $\mathrm{K}$ (cmol kg ${ }^{-1}$ soil) & 0.19 & 0.17 \\
\hline Available S ( $\mu \mathrm{g} \mathrm{g}^{-1}$ soil) & 11.86 & 10.00 \\
\hline
\end{tabular}

Approximately 40kg soils from each location (Madhupur for acid soil and BAU farm for non-calcareous soil) were collected from $0-15 \mathrm{~cm}$ depth of selected fellow land for the experiment. The samples were made free from plant residues and other extraneous materials, air dried, ground and sieved through a $2 \mathrm{~mm}$ sieve. $500 \mathrm{~g}$ sieved soil from each source was preserved in a polythene bag and the physical and chemical properties were analyzed following standard procedure (Page et al. 1982).

Eight $\mathrm{kg}$ processed soil was taken in each earthen pot of $23 \mathrm{~cm}$ in height with $30 \mathrm{~cm}$ diameter at top and $18 \mathrm{~cm}$ at bottom leaving $3 \mathrm{~cm}$ from the top. In vitro produced 45 day old stevia seedlings (Stevia rebaudiana Bertoni) were collected from brac biotechnology laboratory, Joydebpur, Gazipur and used for the experiment. One stevia seedling was planted in each pot during $1^{\text {st }}$ week of March, 2012. P, K, S, Zn and B were applied as basal doses @ 100, 200, 30, 3 and $1 \mathrm{~kg} \mathrm{ha}^{-1}$ from TSP, MoP, gypsum, zinc sulphate and boric acid, respectively. Foliar spray of prilled urea @ 0, 0.5, 1.0, 1.5, 2.0, 2.5 and 3.0g $2 \mathrm{~L}^{-1}$, respectively, were prepared using distilled water and applied at 7 day interval 10 days after planting (DAP) as per treatments. The controlled pot was sprayed only with distilled water. The experiment was laid out in completely randomized design with three replications. Total number of pots was 42 (7 treatment $X 2$ soil $X 3$ replication). Intercultural operations like irrigation, soil loosening, weeding, insect pest control, removal of flowers etc. were done as and when necessary. Data were collected at 15, 30, 45 and 60 DAP. The crop was destructively harvested at 60 DAP. After harvesting the crop, leaf samples were separated, cleaned, dried at $60^{\circ} \mathrm{C}$ for 72 hours, weighed, ground and stored. Plant height, branches plant $^{-1}$, leaves plant ${ }^{-1}$, leaf area plant ${ }^{-1}$, fresh and dry leaf weight of stevia leaves were studied. $N$ content was determined by micro Kjeldahl method (Page et al., 1982). Uptake was calculated from $\mathrm{N}$ content and leaf dry yield. The results obtained were subjected to statistical analysis using standard method of analysis (Steel et al., 1997). The differences among the treatment means were compared by using Duncan Multiple Range test (Gomez, 1984).

\section{Results}

\section{Effects of foliar application of urea on the growth and leaf yield of stevia.}

Seven doses of urea by foliar application were used to study the growth, yield components, leaf biomass yield, $\mathrm{N}$ content and uptake by stevia. The results are described under the following heads. 


\section{Plant height}

The data on plant height as affected by different rates of foliar application of urea in acid and noncalcareous soil is given in Fig 1. Different urea rates had significant effect on plant height of stevia. The applications of urea influenced plant height variably from 15 to 60 DAP. There was a general trend of increase in plant height with increase in urea fertilizer at 15, 30, 45 and 60 DAP with the control treatment registering the least. In the first stage of growth, differences between urea levels were not significant. After this stage, increased plant height and difference between treatments could be observed. An increase in plant height was observed from planting stage to harvesting in both soils irrespective of treatments. Urea application at all levels increased plant height by 22 to $47 \mathrm{~cm}$ in acid soil and 11 to $34 \mathrm{~cm}$ in non-calcareous soil, respectively. It was observed that the pots subjected to $U_{1.0}, U_{1.5}$ and $U_{2.5}$ produced identical plant height but significantly different from those subjected to $U_{0.5}$ and $U_{3.0}$ including control at 60 DAP in acid soil. In case of non-calcareous soil, the plants fertilized with $U_{1.0}$ and $U_{1.5}$ produced identical plant height. Urea @ 2.0g produced the tallest plant $(90.3 \mathrm{~cm})$ and the shortest plants formed in the control (without urea) treatment in both soils. Height increase was $107 \%$ higher in acid soil and $60 \%$ in non-calcareous soil over control.
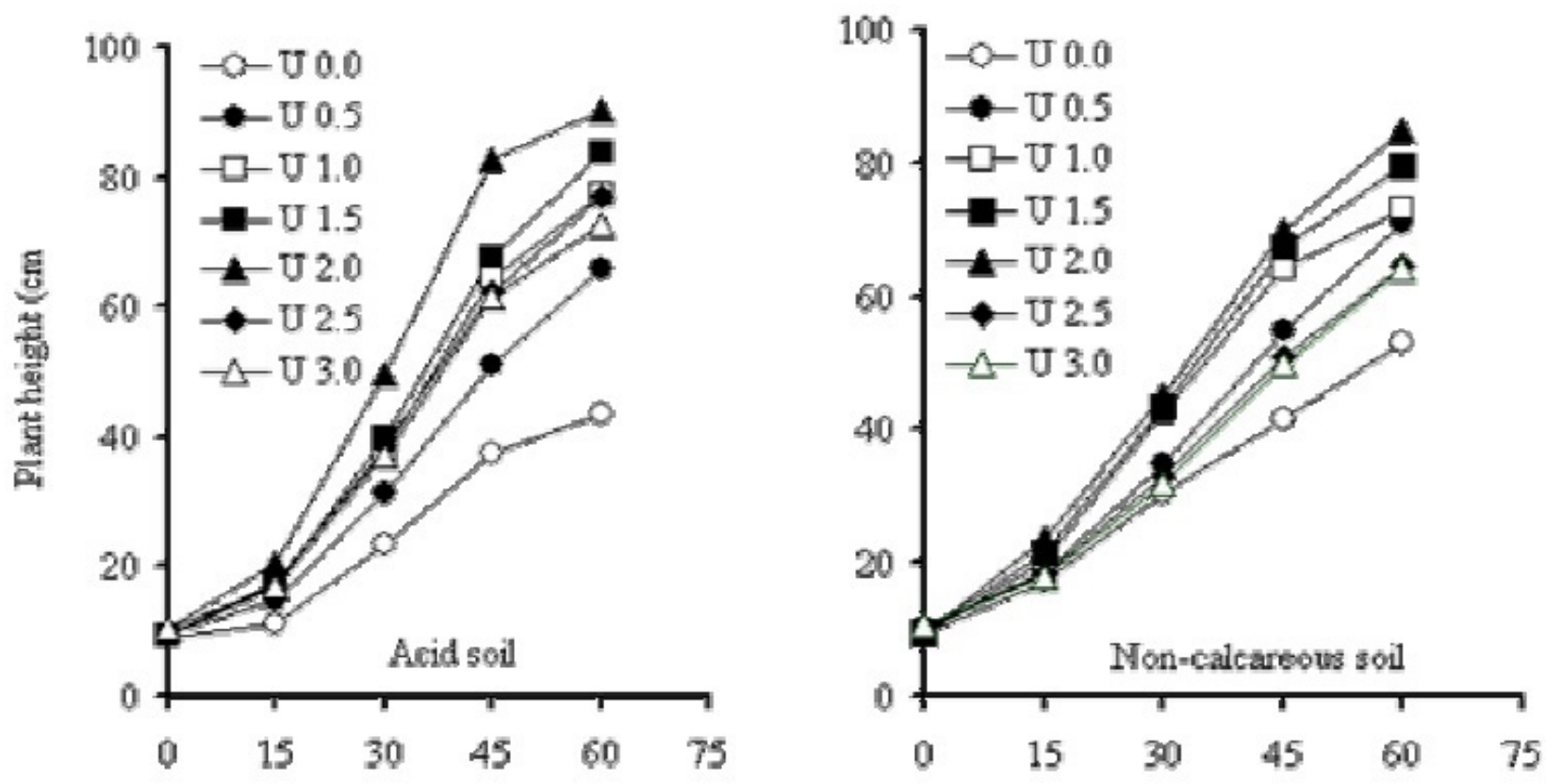

\section{Days after planting (DAP)}

Fig. 1. Effects of different levels of foliar application of urea on the plant height of stevia at various DAP

\section{Branch number}

The data on branch number as influenced by different levels of urea are presented in Fig. 2. Branch number plant $^{-1}$ responded significantly due to the application of different levels of urea. The result revealed that branches plant ${ }^{-1}$ progressively increased with increasing levels of urea application up to $2.0 \mathrm{~g}$ in both soils and then declined with further addition. The application of urea influenced the number of branches plant ${ }^{-1}$ variably from 15 to 60 DAP irrespective of soils and treatments. Rapid increase in branch number was observed between 15 and 45 DAP and then remained constant or very slowly increased in both soils. The highest number of branches plant ${ }^{-1}(9.0$ in acid soil and 10.0 in non-calcareous soil) at 60 DAP was counted from the plant receiving $2.00 \mathrm{~g}$ urea which was identical with $U_{1.5}$ and $U_{2.5}$ but significantly different from other urea treatments including control. The lowest branch number was counted from the control treatment. Urea application at all levels increased branch number by $67-200 \%$ in acid soil and 77 to $233 \%$ in non-calcareous soil, respectively over control at 60 DAP. 

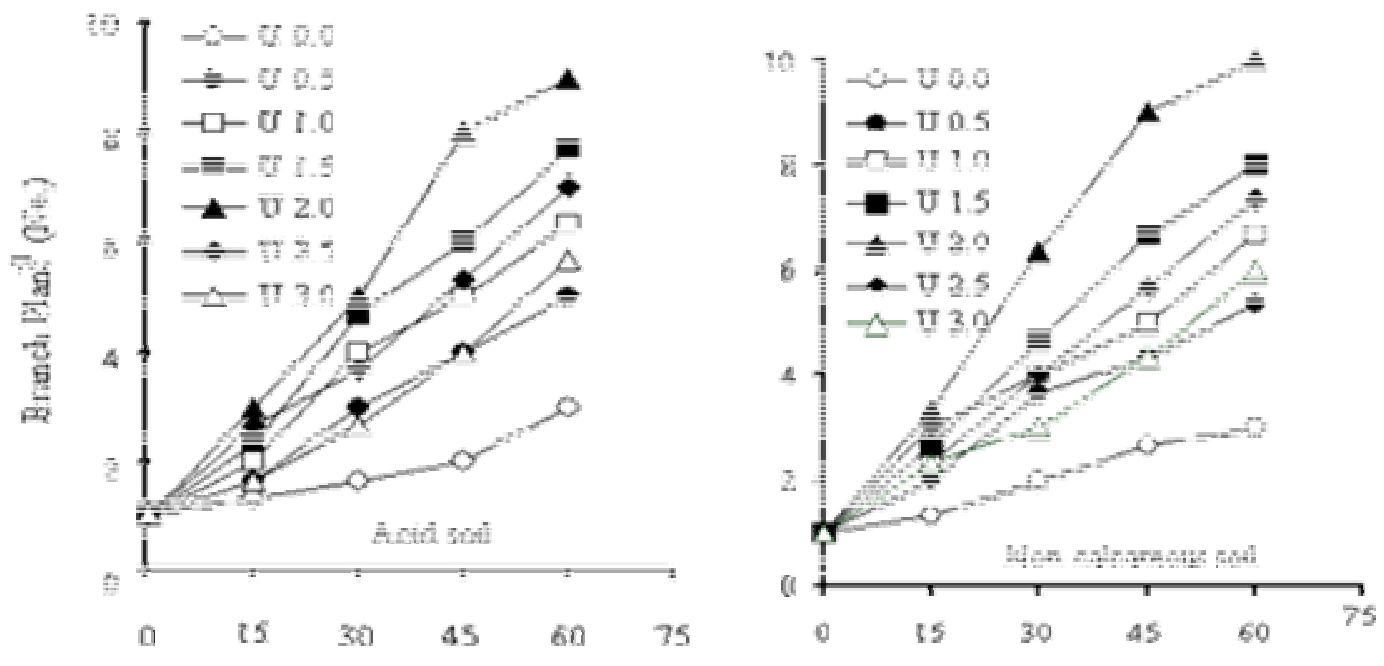

Days after planting (DAP)

Fig. 2. Effects of different levels of foliar application of urea on the branch number of stevia at various DAP

\section{Leaf number}

The data pertaining to the number of leaves plant ${ }^{-1}$ as influenced by different levels of urea in both acid and non-calcareous soils at various DAP have been presented in Fig. 3. Application of urea at different doses significantly influenced the number of leaves of stevia plants at all growth stages except 0 DAP irrespective of soils and treatments used. Leaf number was increased with the increased levels of urea up to $2.0 \mathrm{~g}$ and then declined with further additions $\left(\mathrm{U}_{2.5}\right.$ and $\left.\mathrm{U}_{3.0}\right)$. Leaf number increase was very slow at the early growth stages (0-30 DAP) while it was rapid between 30 and 60 DAP irrespective of urea levels except control. Urea application at all levels increased the number of leaves by 70 to 173 in acid soil and 72 to 199 in non-calcareous soil, respectively. Highest number of leaves was recorded when $U_{2.0}$ was applied which was identical with $\cup_{2.5}$ but significantly higher than all other levels of urea in both soils. Plants fertilized with $U_{2.5}$ and $U_{1.5}$ produced identical number of leaves in both soils. The lowest number of leaves plant $^{-1}$ was harvested from the plants fertilized with no urea irrespective of soils and growth period.
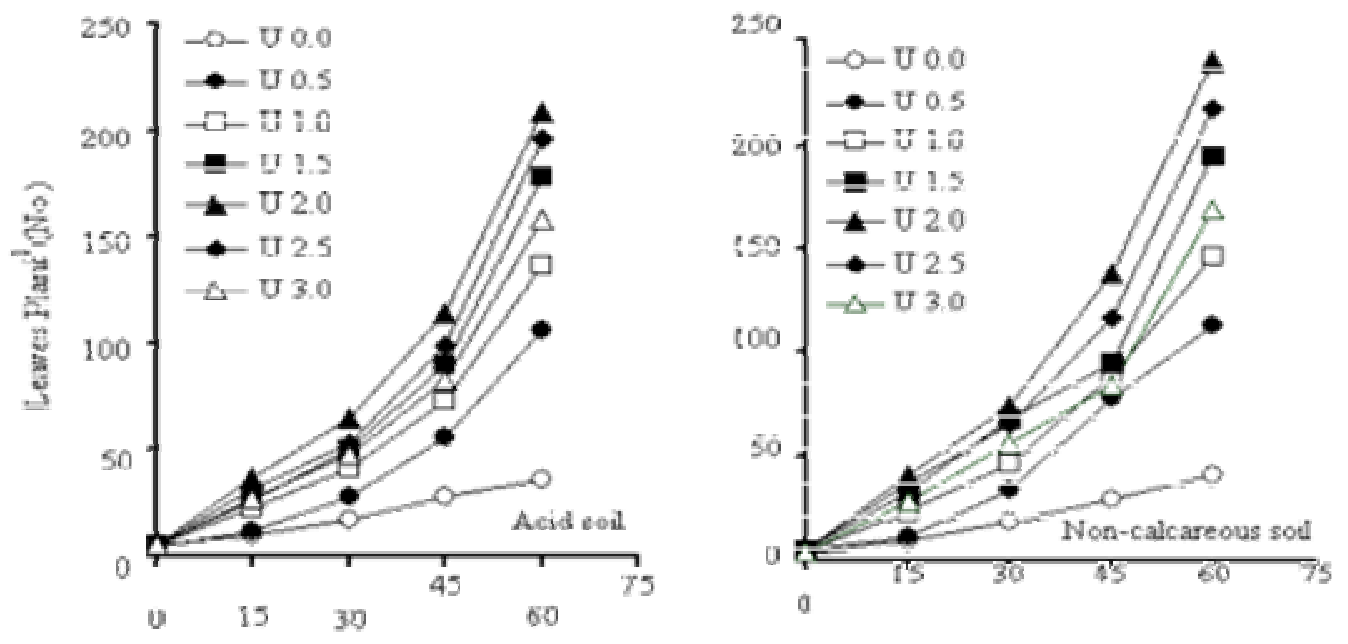

Days after planting (DAP)

Fig. 3. Effects of different levels of foliar application of urea on the leaf number of stevia at various DAP 


\section{Leaf area}

The data on total leaf area plant ${ }^{-1}$ at harvest as influenced by different levels of urea are presented in Table 2. Leaf area plant ${ }^{-1}$ responded significantly due to the application of different levels of urea. The result revealed that leaf area progressively increased with increasing levels of urea application up to $2.0 \mathrm{~g}$ in both soils and then declined with further additions. The highest total leaf area plant ${ }^{-1}\left(1490 \mathrm{~cm}^{2}\right.$ in acid soil and $1932 \mathrm{~cm}^{2}$ in non-calcareous soil) at 60 DAP was measured from the plant receiving $2.0 \mathrm{~g}$ urea which was significantly higher than other levels of urea except $U_{1.5}$ and $U_{2.5}$. Second highest values of $1058 \mathrm{~cm}^{2}$ were obtained from the plant fertilized with $U_{2.5}$ in acid soil and $1266 \mathrm{~cm}^{2}$ from $U_{1.5}$ in noncalcareous soil. The lowest leaf area was found from the control treatment irrespective of soils used. Urea application at all levels increased leaf area by $236-798 \%$ in acid soil and 255 to $944 \%$ in non-calcareous soil, respectively over control at harvest.

Table 2. Effects of different levels of foliar application of urea on leaf area, dry weight and yield increase of stevia leaves over control at harvest

\begin{tabular}{|l|c|c|c|c|c|c|}
\hline \multirow{3}{*}{ Urea level } & \multicolumn{2}{|c|}{ Leaf area plant $^{-1}\left(\mathrm{~cm}^{2}\right)$} & \multicolumn{2}{|c|}{ Leaf dry weight $\left(\right.$ g plant $\left.^{-1}\right)$} & \multicolumn{2}{|c|}{ Increase over control (\%) } \\
\cline { 2 - 7 } & $\begin{array}{c}\text { Acid } \\
\text { soil }\end{array}$ & $\begin{array}{c}\text { Non-calcareous } \\
\text { soil }\end{array}$ & $\begin{array}{c}\text { Acid } \\
\text { soil }\end{array}$ & $\begin{array}{c}\text { Non- } \\
\text { calcareous soil }\end{array}$ & $\begin{array}{c}\text { Acid } \\
\text { soil }\end{array}$ & $\begin{array}{c}\text { Non- } \\
\text { calcareous soil }\end{array}$ \\
\hline$U_{0.0}$ & $166 \mathrm{~d}$ & $185 \mathrm{c}$ & $1.08 \mathrm{f}$ & $1.24 \mathrm{f}$ & - & - \\
\hline$U_{0.5}$ & $558 \mathrm{c}$ & $656 \mathrm{bc}$ & $3.20 \mathrm{e}$ & $3.41 \mathrm{e}$ & 196 & 175 \\
\hline$U_{1.0}$ & $782 \mathrm{bc}$ & $821 \mathrm{bc}$ & $4.14 \mathrm{~d}$ & $4.41 \mathrm{~d}$ & 283 & 256 \\
\hline$U_{1.5}$ & $1007 \mathrm{ab}$ & $1266 \mathrm{ab}$ & $5.39 \mathrm{bc}$ & $5.89 \mathrm{bc}$ & 399 & 375 \\
\hline$U_{2.0}$ & $1490 \mathrm{a}$ & $1932 \mathrm{a}$ & $6.32 \mathrm{a}$ & $7.26 \mathrm{a}$ & 478 & 485 \\
\hline$U_{2.5}$ & $1058 \mathrm{ab}$ & $1246 \mathrm{ab}$ & $5.93 \mathrm{ab}$ & $6.56 \mathrm{ab}$ & 449 & 429 \\
\hline$U_{3.0}$ & $808 \mathrm{bc}$ & $874 \mathrm{bc}$ & $4.78 \mathrm{~cd}$ & $5.09 \mathrm{~cd}$ & 343 & 310 \\
\hline $\mathrm{CV}(\%)$ & 3 & 5 & 2.91 & 2.99 & - & - \\
\hline LSD & 154 & 406 & 0.47 & 0.52 & - & - \\
\hline$S E \pm$ & 77 & 136 & 0.38 & 0.43 & - & - \\
\hline
\end{tabular}

$\mathrm{CV}=$ Coefficient of variance, $\mathrm{LSD}=$ Least significant difference, $\mathrm{SE} \pm=$ Standard error of means

\section{Fresh weight}

The fresh weight of stevia leaves plant ${ }^{-1}$ at harvest varied significantly due the application of different levels of urea fertilizer (Fig. 4). Results revealed that fresh weight progressively increased with increasing levels of urea application up to $2.0 \mathrm{~g}$ in both soils and then declined with further additions $\left(\mathrm{U}_{2.5}\right.$ andU $\left.\mathrm{U}_{3.0}\right)$. The highest fresh weight plant ${ }^{-1}$ (23.45g in acid soil and $26.93 \mathrm{~g}$ in non-calcareous soil) at harvest was measured from the plant receiving $U_{2.0}$ which was identical with the fresh weights of the plants fertilized with $\mathrm{U}_{2.5}$ but significantly higher than other levels of urea. Second highest values $(22.00 \mathrm{~g}$ in acid soil and $24.35 \mathrm{~g}$ in non-calcareous soil) were obtained from $U_{2.5}$. The lowest values were obtained from the control treatment $(4.00 \mathrm{~g}$ in acid soil and $4.60 \mathrm{~g}$ in non-calcareous soil) irrespective of soils used. Urea application at all levels increased fresh weight at harvest by 7.86 to $19.45 \mathrm{~g} \mathrm{plant}^{-1}$ in acid soil and 8.04 to $22.33 \mathrm{~g}$ plant $^{-1}$ in non-calcareous soil, respectively. 


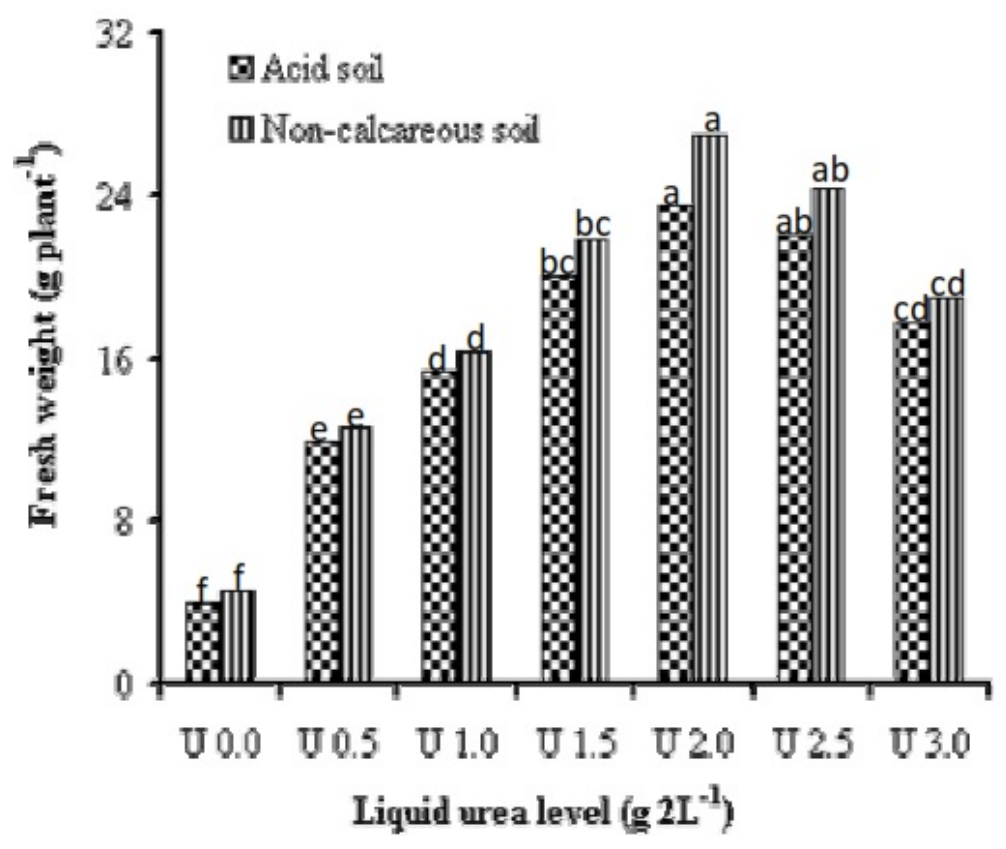

Fig. 4. Effects of different levels of foliar application of urea on the fresh weight of stevia leaves at harvest

\section{Dry weight}

The dry weight of stevia leaves plant ${ }^{-1}$ at harvest varied significantly due the application of different levels of urea fertilizer (Table 2). Results revealed that dry weight progressively increased with increasing levels of urea application up to $2.0 \mathrm{~g}$ in both soils and then declined with further additions $\left(U_{2.5}\right.$ and $\left.U_{3.0}\right)$. The highest dry weight plant ${ }^{-1}$ (6.32g in acid soil and $7.26 \mathrm{~g}$ in non-calcareous soil) at harvest was measured from the plant receiving $2.0 \mathrm{~g}$ urea which was identical with the dry weights of the plants treated with $\mathrm{U}_{2.5}$ but significantly higher than other levels of urea. Second highest values $(5.93 \mathrm{~g}$ in acid soil and $6.56 \mathrm{~g}$ in non-calcareous soil) were obtained from $U_{2.5}$. The lowest values were obtained from the control treatment (1.08g in acid soil and $1.24 \mathrm{~g}$ in non-calcareous soil). Urea application at all levels increased leaf dry yield at harvest by 196 to $478 \%$ in acid soil and 175 to $485 \%$ in non-calcareous soil, respectively over control.

\section{$\mathrm{N}$ content and uptake}

Different levels of foliar application of urea significantly affected the $\mathrm{N}$ content and uptake by stevia leaf at harvest (Table 3). $\mathrm{N}$ content of the leaf was increased with the increased levels of urea irrespective of soils used. The highest $\mathrm{N}$ content $(2.11 \%$ in acid soil and $1.99 \%$ in non-calcareous soil) was obtained when urea was applied @ $3 \mathrm{~g}$ in both soils which was statistically identical with the $\mathrm{N}$ contents of the leaves of stevia plant fertilized with $U_{2.5}$ in non-calcareous soil but significantly different from other treatments. The lowest $\mathrm{N}$ content was obtained from the plants receiving distilled water only in both soils. The trend of $\mathrm{N}$ uptake did not follow the trend of $\mathrm{N}$ contents of stevia leaves. The $\mathrm{N}$ uptake varied from 12.64 to $104.91 \mathrm{mg} \mathrm{pot}^{-1}$ in acid soil and 13.64 to $132.86 \mathrm{mg} \mathrm{pot}^{-1}$ in non calcareous soil. $\mathrm{N}$ uptake as expected increased as foliar urea levels increased up to $2.0 \mathrm{~g}$ and then decreased with further addition $\left(\mathrm{U}_{2.5}\right.$ and $\left.\mathrm{U}_{3.0}\right)$. Like $\mathrm{N}$ content, the lowest uptake was observed in the control treatment of both soils. 
Table 3. Effects of different levels of foliar application of urea on the $\mathbf{N}$ content and uptake by stevia leaf at harvest

\begin{tabular}{|c|c|c|c|c|}
\hline \multirow{3}{*}{$\mathrm{N}$ level } & \multicolumn{4}{|c|}{ Nitrogen } \\
\hline & \multicolumn{2}{|c|}{ Acid soil } & \multicolumn{2}{|c|}{ Non-calcareous soil } \\
\hline & $\begin{array}{c}\text { Content } \\
(\%)\end{array}$ & $\begin{array}{c}\text { Uptake } \\
\left(\mathrm{mg} \mathrm{pot}^{-1}\right)\end{array}$ & $\begin{array}{c}\text { Content } \\
\text { (\%) }\end{array}$ & $\begin{array}{c}\text { Uptake } \\
\left(\mathrm{mg} \mathrm{pot}^{-1}\right)\end{array}$ \\
\hline $\mathrm{U}_{0.0}$ & $1.17 f$ & $12.64 d$ & $1.10 \mathrm{e}$ & $13.64 \mathrm{e}$ \\
\hline $\mathrm{U}_{0.5}$ & $1.19 f$ & $37.12 c$ & $1.37 d$ & $46.72 d$ \\
\hline$U_{1.0}$ & $1.33 e$ & $55.06 c$ & $1.55 d$ & $68.36 \mathrm{c}$ \\
\hline$U_{1.5}$ & $1.48 d$ & $79.77 b$ & $1.71 \mathrm{c}$ & $100.72 b$ \\
\hline $\mathrm{U}_{2.0}$ & $1.66 \mathrm{c}$ & $104.91 \mathrm{a}$ & $1.83 b$ & $132.86 \mathrm{a}$ \\
\hline $\mathrm{U}_{2.5}$ & $1.81 \mathrm{~b}$ & $98.44 a$ & $1.92 a$ & $125.95 a b$ \\
\hline $\mathrm{U}_{3.0}$ & $2.11 \mathrm{a}$ & $100.86 a$ & $1.99 a$ & $101.29 b$ \\
\hline CV (\%) & 3.36 & 4.39 & 3.97 & 5.29 \\
\hline $\mathrm{LSD}_{0.05}$ & 0.02 & 5.19 & 0.01 & 6.23 \\
\hline SE \pm & 0.02 & 1.75 & 0.01 & 2.09 \\
\hline
\end{tabular}

$\mathrm{CV}=$ Coefficient of variance, $\mathrm{LSD}=$ Least significant difference, SE \pm = Standard error of means

\section{Discussion}

Smaller quantities of the fertilizer material are required if is applied as foliar spray than that applied directly in the soil. The danger of fixation and/or leaching is also reduced when nutrients are applied to the foliage of the plant. Foliage generally absorbs nutrients more rapidly than when applied to the soil. The application of foliar fertilizer is the quickest way to deliver nutrients to the tissues and organs of the crops as well as the quickest means of replacing nutrient deficiencies. The results are discussed under the following heads.

\section{Leaf yield and yield attributes}

Foliar fertilization involves the application of soluble fertilizer to the foliage of crop plants, in the form of a diluted aqueous spray. From the applied solution, the plant takes up the nutrients in ionic form, through the leaves and other aerial organs. Supplying plants with adequate nutrition is an important aspect of maintaining their health and performance, and foliar sprays have been used for a long time as a source of the necessary nutrients. Foliar sprays can give the crops a nutritional boost that results in increased yields, higher quality, improved resistance to disease and insect attack, and enhanced drought tolerance. In this experiment, highest yield attributes viz. plant height, branch number, leaf area and leaf number, fresh and dry leaf yield of stevia were obtained when foliar urea was applied @ $2 \mathrm{~g}$ and then remained constant or decreased. The lowest values of all the parameters were found in the control treatment. This result is in accordance with the findings of Khosha et al. (2011) who found highest plant height, branch number, leaf area and leaf number of gerbera applying liquid urea @ $2 \mathrm{~g} \mathrm{~L}^{-1}$. Yildrim et al. (2007) also reported highest values of all the studied parameters of broccoli from the foliar application of $1 \%$ urea solution. These results are in line with Khan et al. (2009) who reported that the foliar spray of $4 \%$ urea solution was most effective for enhancing the quantitative and qualitative traits when sprayed at tillering, stem elongation and booting stage. The grain yield was increased by $32 \%$ when $4 \%$ urea solution was applied as foliar spray. Further increase in the concentrations of urea spray was not useful and economical as it declined the grain yield by $25 \%$ or even more probably due to its toxicity.

\section{$\mathrm{N}$ content and uptake}

Different levels of foliar application of urea significantly affected the $\mathrm{N}$ content and uptake by stevia leaf at harvest. $\mathrm{N}$ content of the leaf was increased with the increased levels of urea irrespective of soils used. $\mathrm{N}$ uptake did not follow the trend of $\mathrm{N}$ content of stevia leaves. $\mathrm{N}$ uptake as expected increased with the increase in foliar application of urea up to $2.0 \mathrm{~g}$ and then decreased with further addition $\left(U_{2.5}\right.$ and $\left.U_{3.0}\right)$ irrespective of soils used. Both $\mathrm{N}$ content and uptake by stevia was higher in acid soil than non- calcareous soil. 
Khan et al. (2009) reported that foliar application of urea significantly increased the $\mathrm{N}$ uptake by wheat. The foliar spray of $4 \%$ urea solution was found to be most effective dose for $\mathrm{N}$ uptake by wheat. The high efficiency of foliar urea application found in this study is in agreement with the findings of Yildrim et al. (2007) who found highest $\mathrm{N}$ uptake by broccoli leaf applying $1 \%$ urea solution. Zahran and Abdoh (1998) found better result for onion and Zeidan (2003) for faba bean. The later recommended that urea might be used as foliar $\mathrm{N}$ source to obtain better growth, yield, $\mathrm{N}$ content and uptake.

\section{Conclusion}

Foliar application of urea significantly increased yield attributes and leaf $\mathrm{N}$ content and uptake by stevia. Most of the parameters were increased with the advancement of growth period from 30 to 60 DAP. The foliar spray of $2.0 \mathrm{~g}$ urea solution was found to be most effective for enhancing the growth, leaf yield and yield attributes of stevia. The yield increase was $478 \%$ in acid soil and $485 \%$ in non-calcareous soil over control. Further increase in the concentrations of urea spray $(2.5$ and $3.0 \mathrm{~g})$ was not found to be useful as it declined the leaf yield by $135 \%$ in acid and $175 \%$ in non-calcareous soil probably due to its toxicity. In regard to the $\mathrm{N}$ content, it can be inferred that foliar urea applications increased $\mathrm{N}$ content in stevia leaves irrespective of soils with the increased levels of urea. The highest values were obtained from $3.0 \mathrm{~g}$ urea application for the plants grown in both soils. Conversely, the trend of $\mathrm{N}$ uptake did not follow the trend of $\mathrm{N}$ contents of stevia leaves. $\mathrm{N}$ uptake as expected increased as foliar application of urea increased up to $2.0 \mathrm{~g}$ and then decreased with further addition.

\section{Acknowledgement}

We are thankful to the authority of Bangladesh Agricultural Research Council (BARC), Farmgate, Dhaka for financial support.

\section{References}

Bajwa, M. I. 1992. Soil fertility management for sustainable agriculture. Proc. 3rd National Congress of Soil Science, held at Lahore from 20th to 22nd March 1990. pp: 7-25.

Gomez, K.A. and Gomez, A.A. 1984. Statistical Procedure for Agricultural Research. $2^{\text {nd }}$ edn. International Rice Research Institute. Los Banos, Philippines. pp. 207-215.

Khan, P., Memon, M.Y., Imtiaz, M. and Aslam, M. 2009. Response of wheat to foliar and soil application of urea at different growth stages. Pakistan Journal of Botany 41 1197-1204.

Khosa, S.S., Younis, A., Rayit, A., Yasmeen, S. and Riaz, A. 2011. Effect of foliar application of macro and micro nutrients on growth and flowering of Gerbera jamesonii L. American-Eurasian Journal of Agriculture and Environmental Science 11 736-757.

Kolata, E. and Osinska, M. 2001. Efficiency of foliar nutrition of field vegetables grown at different nitrogen rates. In: Proc. IC Environ. Probl. N-Fert. Acta Hort., 563 87-91.

Mosluh, K.I., Seth, J. and Rashid, A.K.K. 1978. Efficacy of urea spray for wheat crop under irrigated conditions in Iraq. Plant and Soil, 49: 175-178.

Padem, H. and Yildirim, E. 1996. Effect of foliar fertilizer on yield and yield components of summer squash (Cucurbita pepo L.). $1^{\text {st }}$ Egypt.-Hung. Hort. Abstr. Conf. Karf El-Sheikh, Egypt.

Page, A.L., Miller, R.H. and Keeney, D.R. (eds). 1982. Method of Soil Analysis, Part-2 Chemical and Microbiological Properties, $2^{\text {nd }}$ edn., American Society of Agronomy, Inc. Madison, Wisconsin, USA.

Raun, W. R. and Johnson, G.V. 1999. Improving nitrogen use efficiency for cereal production. Agron. J., 91: 357-363.

Steel, R.G.D., Torrie, J.H. and Dickey, D. 1997. Principles and Procedures of Statistics: A biometrical approach. 3rd Ed. McGrawHill Book Co., New York, USA.

Witte, C.P., Tiller, S.A., Taylor, M.A. and Davies, H.V. 2002. Leaf urea metabolism in potato. Urease activity profile and patterns of recovery and distribution of ${ }^{15} \mathrm{~N}$ after foliar urea application in wild-type and ureas-anti-sense transgenics. Plant Physiology 128 1129-1136.

Wojcik, P. 2004. Uptake of mineral nutrients from foliar fertilization. Journal of Fruit and Ornamental Plant Research 12 $201-218$.

Yildirim, E., Guvenc, I., Turan, M. and Karatas, A. 2007. Effect of foliar urea application on quality, growth, mineral uptake and yield of broccoli (Brassica oleracea L., var. italica). Plant soil environment 53 120-128.

Zahran, F.A. and Abdoh, A.E. 1998. Nitrogen fertilization of onion in sandy soils. Egyptian Journal of Agricultural Research $76903-$ 911.

Zeidan, M.S. 2003. Effect of sowing dates and urea foliar application on growth and seed yield of faba bean (Vicia faba L.) under Egyptian conditions. Egyptian Journal of Agronomy 24 93-102. 